MORALITY, RULES, AND CONSEQUENCES 



\title{
MORALITY, RULES, AND CONSEQUENCES
}

A Critical Reader

\author{
Edited by Brad Hooker, \\ Elinor Mason, and Dale E. Miller
}


(C) The Contributors, 2000

Transferred to digital print 2008

Edinburgh University Press Ltd

22 George Square, Edinburgh

Typeset in Fournier

by Hewer Text Ltd, Edinburgh, and printed and bound in Great Britain by CPI Antony Rowe, Chippenham and Eastbourne

A CIP record for this book is available from the British Library

ISBN 0748611282 (hardback) ISBN 0748611746 (paperback)

The right of the contributors to be identified as authors of this work has been asserted in accordance with the Copyright, Designs and Patents Act 1988. 